3 日間食事記録調査における写真撮影の有効性

今井具子 $\cdot$ 大塚 礼 $\cdot$ 加藤友紀 $\cdot$ 中村美恵子 安藤富士子・下方浩史

$(* 1)$ 東海学園大学人間健康学部管理栄養学科, ${ }^{* 2}$ 国立長寿医療センター研究所疫学研究部,

*3) 浜松医科大学健康社会医学講座, *4) 愛知淑徳大学医療福祉学部医療貢献学科)

\title{
Advantages of Taking Photographs with the 3-Day Dietary Record
}

Tomoko Imai*1) $\cdot$ Rei Otsuka*2) $\cdot$ Yuki Katou*2) $\cdot$ Mieko Nakamura*3) - Fujiko Ando ${ }^{* 4)} \cdot$ Hiroshi Shimokata*2)

*1) Department of Registered Dietitians, Faculty of Human Wellness, Tokaigakuen University, 2-901 Nakahira Tenpaku-ku Nagoya, 468-8514, JAPAN

*2) Department of Epidemiology, National Institute for Longevity Sciences, National Center Geriatrics and Gerontology 36- 3 Gengo Morioka-cho Obu Aichi, 474-8522, JAPAN

*3) Department of Community Health and Preventive Medicine, Hamamatsu University School of Medicine, 1-20- 1 Handayama, Higashi-ku, Hamamatsu 431-3192, Japan

* ${ }^{*}$ Department of Community Care Philanthropy, Faculty of Medical Welfare, Aichi Shukutoku University, 23 Sakuragaoka Chikusa-ku Nagoya 464-8671, Japan

${ }^{* 1}$ ) 个468-8514 名古屋市天白区中平 2-901

*2) ₹474-8522 愛知県大府市森岡町源吾 36- 3

*3) 于431-3192 浜松市東区半田山 1-20-1

*4) T464-8671 名古屋市千種区桜が丘 23

目的：国立長寿医療センター研究所・老化に関する長期縦断疫学研究 (NILS-LSA) では写真を併用した 3 日間秤量法による食事記録（3 DR）を行っている。対象者に は $3 \mathrm{DR}$ を記録する際に各食事の食前・食後の写真撮影を依頼している。栄養士は 3 DR に記載された食品名と食品量を推定する際に必要があれば写真を利用する。本 研究の目的は対象者が記入した食品名と食品量を訂正する際に写真が有効であるか どうかを明らかにすることである。

方法：対象者 $(\mathrm{n}=100)$ が記録した食品名と食品量を記録形式で分類した。

結果：対象者が記録した食品のうち秤量されたものは $49 \%$ （6\%は写真を用いて訂 正), 目安量で記録されたものは $23 \%$ ( $3 \%$ は写真訂正), 料理で記録されたものは $8 \%$ ( $5 \%$ は写真訂正), 記入漏れは21\%（うち $14 \%$ が栄養士が写真より追加訂正）であっ た。記入漏れ食品は $25 \%$ が野菜類, $20 \%$ が調味料類であった。

結論：3 DRの情報をより正確にする，あるいは訂正するためには，特に野菜類や調 味料など対象者が記入漏れしやすい食品については, 写真が有効である可能性が示 された。 
Food frequency questionnaires $(\mathrm{FFQ})$ and 24-hour dietary recall have been widely used by nutrition epidemiologists to estimate the food and nutrient intake of the general public. However, the most accurate method currently for measuring food intake is by weighing the food and keeping a dietary record (DR). No method is able to accurately measure nutrient intake without error. Minimizing measurement error is the key element in the successful elucidation of nutrient assessment in nutritional epidemiological studies ${ }^{1-3)}$.

Most errors in the assessment of nutrient intake from DR occur when the subjects assess the amounts of food they consume ${ }^{1-3)}$. Weighing accuracy is a major source of error. It is difficult for subjects to weigh food accurately because some foods were weighed when they contained refuse parts such as vegetables with skin, fish with viscera and scales etc.. Some foods were too light to weigh such as seaweed, or instant coffee $e t c$.. The accuracy of estimating portion sizes also causes errors ${ }^{1)-5}$. It is difficult for subjects to estimate the portion sizes of some foods, particularly additional foods (e.g. seasoning) even with the use of a quantification tool, such as food models, pictures, or photographs ${ }^{4}$. Sometimes food information on portion size is incomplete or not available, especially from subjects who ate out ${ }^{3), 6}$. When information about portion size was missing, the subjects would be asked again about individual portion sizes. If individual portion size could not be found, standard portion sizes were used $^{6)-8)}$. Errors occurred when researchers estimated portion sizes using standard portion sizes, as well as when the subjects estimated the portion sizes by themselves ${ }^{1)-3), 7), 8}$.

Some studies have reported advantages in using photographs to help subjects assess portion sizes ${ }^{4), 5), 9)}$, and the other studies have reported when subjects took pictures of their meals and snacks instead of just written records the additional information was useful ${ }^{10), 11}$. However, the advantages of photographic evidence to estimate the kinds and amounts of food with 3 DR have not been clearly defined. We asked the subjects to take photographs before and after each meal while keeping a 3 -day dietary record ( $3 \mathrm{DR}$ ) in this study as part of the nutritional survey of the National Institute for Longevity Science-Longitudinal Study of Aging (NILS-LSA). Well-trained dietitians estimated the kinds and amounts of food intake using the $3 \mathrm{DR}$, and photographs, if necessary ${ }^{12)}$.

The purpose of this study was to clarify the following two points; 1 ) the reported food portions by the subjects were initially categorized into six reporting style categories (weighed, reported by portion size, dish or food name only, erroneously reported, unreported, and leftover) and further subdivided into three subcategories depending on the meal style (dishes, foods, or seasoning), and we compared the advantage of photographs among the categories; and 2 ) the kinds and amounts of food unreported by the subjects and nutritional intake from unreported food because the results from 1 ) showed the importance in using photographic evidence for error correction of unreported food by the subjects.

\section{METHODS}

\section{Subjects}

The subjects were a part of the participants of the first wave examination of the NILS-LSA. The NILS-LSA is a comprehensive population-based longitudinal study of aging, which started in 1997. The participants were stratified by both age and sex, and were selected randomly from resident registrations in the city of $\mathrm{Obu}$ and town of $\mathrm{Hi}-$ gashiura, Aichi in Japan. The numbers of men and women recruited were similar and the baseline age was 40 to 79 years, with similar numbers of participants in each decade (40s, 50s, 60s, 70s). The participants of the first wave examination included 2,267 men and women and they were followed up biennially. All participants gave their informed consent before they participated in the study. Details of the study purpose, design, and examination procedures have been described elsewhere ${ }^{13)}$.

The subjects in this study were 63 men $(59.2 \pm 10.8$ years of age, mean \pm S.D.) and 37 women $(57.5 \pm 10.8$ years of age), who were the participants in the NILS-LSA between December 1999 and January 2000, selected sequentially up to 100 men and women, excluding participants who did not return 3 DR records $(n=8)$. Participants who took less than a total of nine pictures or unavailable pictures were also excluded $(\mathrm{n}=14)$.

Dietary Assessments by usual 3 -day dietary records in this study (usual $3 \mathrm{DR}$ )

The 3 DR method in the NILS-LSA was carried out on three consecutive days (two weekdays and one weekend day). The subjects reported their food amounts by weighing with a scale (SEKISUI COOKING SCALE MEAL wt; $1 \mathrm{~kg}$, minimum; $5 \mathrm{~g}$ ) (henceforth referred to as "weighed"), or by estimation of their food by portion sizes (henceforth referred to as "portion size"). The subjects took photographs of the meals before and after eating with a disposable camera (FUJICOLOR QuickSnap SUPERIA, FUJICOLOR SUPERIA X-TRA 800) ISO 800/30 ) 135 - 27 exp.). Trained dietitians explained for 30 minutes how to record the $3 \mathrm{DR}$ and how to take the photographs of meals with a disposable camera. Dietitians used the photographs to 
confirm the reported $3 \mathrm{DR}$ data or to complete the unreported $3 \mathrm{DR}$ data if needed.

In this study well-trained dietitians for our study reviewed the records and estimated the kinds and the amounts of food in the $3 \mathrm{DR}$ without photographs (henceforth referred to as usual $3 D R$ ). We categorized the food reported by the subjects into three kinds of meal style subcategories; "dishes", which were cooked meals, "foods" that consisted of food excluding seasonings and spices, and "seasonings and spices".

Dietary Assessments by 3 -day dietary records with photographs (Photo\& $3 D R$ )

The same dietitians then used the photographs (printed on L size paper; $89 \mathrm{~mm} \times 127 \mathrm{~mm}$ ) to complete the records and resolve any discrepancies or to obtain further information on the kinds and estimate the amounts of food where necessary. We corrected the following with the aid of the photographic evidence; a) the food names and the amounts of food that were "weighed" by the subjects; b) the food names and the amounts of food reported by "portion size" by the subjects; c) the food names and the amounts of food reported by dish or food name only by the subjects (henceforth referred to as "dish or food name only") ; d) the food names and the amounts of food that were erroneously reported by the subjects (henceforth referred as to "erroneously reported"); e) the food names and the amounts of food that were unreported from the reports by the subjects (henceforth referred as to "unreported"); and f) the food names and the amounts of food that were leftover by the subjects (henceforth referred as to "leftover"). We used the subcategory "before" to denote those food portions that were recorded previously. We used manuals to estimate the kinds and amounts of food if necessary when the dietitians coded the usual $3 D R$ and Photo\& $3 D R^{8}$.

Food and nutrient intake from usual $3 D R$ and Photo\& $3 D R$

The food was divided into 17 food groups and the averages of food and nutrient intakes were calculated according to the fifth edition of the Standard Tables of Foods Composition in Japan ${ }^{14)}$. Food intakes were calculated after converting cooked amounts into raw amounts.

\section{Data Analysis}

The numbers of photographs, the numbers of corrected foods with or without photographs of 1 ) "weighed”, 2) "portion size", 3 ) "dish or food name only", 4 ) "erroneously reported", 5 ) "unreported", and 6 ) "leftover" by the subjects etc. were calculated by meal style subcategories ("dishes", "foods", "seasonings and spices", and "before"). Food and nutrient intakes from usual $3 D R$ and Photo\& $3 D R$ were calculated. The differences and percentage differences were calculated. Data is shown as mean \pm S.D. Statistical comparisons between usual $3 D R$ and Photo\& $3 D R$ were performed with paired t-test and Spearman's product-moment correlation coefficients. "Unreported" food numbers and nutrient intake from "unreported" food were calculated, because "unreported" food might have a meaningful effect on the results. All the statistical analyses were performed using Statistical Analysis System software, version 9.1.35). Differences with $\mathrm{p}$ values less than 0.05 were considered statistically significant.

\section{RESULTS}

During the recording period, the subjects took $19.1 \pm$ 4.0 pictures in total (before eating; $8.9 \pm 0.8$, after eating; $7.2 \pm 2.9$, between-meal snacks etc.; $3.0 \pm 2.8$ ). Among the food-amounts reporting styles in the final data in Photo\& 3 DR (161.5 \pm 33.8 items) by the subjects, $48.9 \%$ of foods were "weighed", $23.4 \%$ of foods were reported by "portion size", and $8.4 \%$ of foods were reported by "food or dish names only" (Table 1). "Unreported" foods comprised $20.9 \%$. and corrected foods with photographs $30.7 \%$. The photographs were only used in $12 \%$ of cases to make corrections when the subjects used either the "weighed" (11.9\%) or the "portion size" (12.7\%) recording styles. In contrast, photographic evidence was crucial for correcting the data of those subjects using the "dish or food name only", being used $62.2 \%$ of cases, and for those who "unreported" to report some food in $67.7 \%$ of cases. Furthermore, the photographic evidence was used almost exclusively to correct "erroneously reported" (100\%) and "leftover" (100\%) foods. In the "weighed" reporting style category, the "dishes" meal style subcategory was corrected most frequently by photographic evidence; $22.2 \%$ for "dishes", $10.5 \%$ for "foods", and $13.4 \%$ for "seasonings and spices". In the "portion size" category, the "seasonings and spices" was the most frequently corrected subcategory using the photographs, 17.6\% for "seasonings and spices", 10.0\% for "dishes", and $9.8 \%$ for "foods". Furthermore, in the "dish or food name only" and "unreported" categories most portion sizes in the "food", "seasonings and spices", and "before" subcategories were corrected using photographic evidence. Finally, almost all food portions in the "erroneously reported" and "leftover" categories had to be corrected in the same manner, regardless of the subcategories.

Food intake from usual $3 D R$ and Photo\& $3 D R$ is shown 
Table 1 The numbers of corrected food items among the final numbers of food items with or without photographs in Photo\& $3 D R$ by the subjects $(n=100)$

\begin{tabular}{|c|c|c|c|c|c|c|c|}
\hline & & & & & Correcte & numbers & \\
\hline & & Total num & abers & With photog & graphs & Without phot & tographs \\
\hline Reporting style category & Meal style subcategory & Mean \pm S.D. & $\begin{array}{c}\text { Ratio to } \\
\text { the final } \\
\text { numbers * } \\
(\%)\end{array}$ & Mean \pm S.D. & $\begin{array}{c}\text { Ratio to } \\
\text { the total } \\
\text { numbers } \\
(\%)\end{array}$ & Mean \pm S.D. & $\begin{array}{c}\text { Ratio to } \\
\text { the total } \\
\text { numbers } \\
(\%)\end{array}$ \\
\hline Weighed by the subjects & Dishes & $7.2 \pm 5.4$ & 4.5 & $1.6 \pm 2.2$ & 22.2 & 0 & 0 \\
\hline & Foods & $61.9 \pm 25.8$ & 38.3 & $6.5 \pm 5.6$ & 10.5 & $0.1 \pm 0.6$ & 0.3 \\
\hline & Seasonings and spices & $9.7 \pm 10.5$ & 6.0 & $1.3 \pm 1.9$ & 13.4 & $0.3 \pm 1.4$ & 3.1 \\
\hline & Total weighed & $78.9 \pm 34.2$ & 48.9 & $9.4 \pm 7.0$ & 11.9 & $0.4 \pm 1.6$ & 0.5 \\
\hline Reported portion size by the subjects & Dishes & $2.0 \pm 3.2$ & 1.2 & $0.2 \pm 0.6$ & 10.0 & 0 & 0 \\
\hline & Foods & $21.5 \pm 15.1$ & 13.3 & $2.1 \pm 2.9$ & 9.8 & $0.2 \pm 1.0$ & 0.9 \\
\hline & Seasonings and spices & $14.2 \pm 9.9$ & 8.8 & $2.5 \pm 3.8$ & 17.6 & $0.3 \pm 0.9$ & 2.1 \\
\hline & Total reported portion size & $37.8 \pm 20.9$ & 23.4 & $4.8 \pm 4.9$ & 12.7 & $0.5 \pm 1.4$ & 1.3 \\
\hline Reported dish or food name only & Dishes & $0.7 \pm 1.8$ & 0.4 & $0.2 \pm 1.1$ & 28.6 & $0.4 \pm 1.1$ & 57.1 \\
\hline by the subjects & Foods & $9.3 \pm 11.1$ & 5.8 & $6.1 \pm 10.1$ & 65.6 & $3.3 \pm 5.8$ & 35.5 \\
\hline & Seasonings and spices & $3.5 \pm 5.3$ & 2.2 & $1.9 \pm 4.0$ & 54.3 & $1.6 \pm 3.2$ & 45.7 \\
\hline & 1otal reported dish or food name only & & & & & $5.1 \pm 8.4$ & \\
\hline Erroneously reported by the & & & & & & & \\
\hline subjects & $\begin{array}{l}\text { Foods } \\
\text { Seasonings and spices }\end{array}$ & $1.2 \pm 1.6$ & 0.7 & $1.2 \pm 1.5$ & 100.0 & $0.01 \pm 0.1$ & 0.8 \\
\hline & Total erroneously reported & $1.3 \pm 1.7$ & 0.8 & $1.3 \pm 1.7$ & 100.0 & $0.01 \pm 0.1$ & 0.8 \\
\hline Unreported food by the subjects & & & & & & & \\
\hline & $\begin{array}{l}\text { Before } \\
\text { Foods }\end{array}$ & $\begin{array}{r}4.3 \pm 7.2 \\
12.6 \pm 9.8\end{array}$ & $\begin{array}{l}1.6 \\
7.8\end{array}$ & $\begin{aligned} 3.7 \pm 7.0 \\
11.4 \pm 9.6\end{aligned}$ & $\begin{array}{l}86.0 \\
90.5\end{array}$ & $\begin{array}{l}0.6 \pm 2.7 \\
1.1 \pm 3.3\end{array}$ & $\begin{array}{r}14.0 \\
8.7\end{array}$ \\
\hline & Seasonings and spices & $17.7 \pm 12.7$ & 11.0 & $7.7 \pm 8.1$ & 43.5 & $10.0 \pm 8.5$ & 56.5 \\
\hline & Total unreported foods & $33.7 \pm 22.2$ & 20.9 & $22.8 \pm 19.6$ & 67.7 & $11.0 \pm 9.4$ & 32.6 \\
\hline Leftover & Foods & $1.8 \pm 2.8$ & 1.1 & $1.7 \pm 2.7$ & 94.4 & $0.01 \pm 0.1$ & 0.6 \\
\hline & Seasonings and spices & $1.1 \pm 2.1$ & 0.7 & $1.0 \pm 1.9$ & 100.0 & $0.07 \pm 0.4$ & 6.4 \\
\hline & Total leftover & $2.8 \pm 4.4$ & 1.7 & $2.8 \pm 4.2$ & 100.0 & $0.08 \pm 0.5$ & 2.9 \\
\hline Final number of food in Photo\& $3 \mathrm{DR}$ & & $161.5 \pm 33.8$ & & $49.5 \pm 28.0$ & 30.7 & $17.1 \pm 13$ & 10.6 \\
\hline
\end{tabular}

Dishes; complete cooked meals

Foods; foods, excluding seasonings and spices

Before; food portions that were previously recorded

*; Total numbers/final numbers $\times 100, \uparrow$; Corrected numbers with photographs/total numbers $\times 100$, $末$; Corrected numbers without photographs/total numbers $\times 100$

Table 2 Comparison of food intakes between usual $3 D R$ and Photo\& $3 D R$ by the subjects $(n=100)$

\begin{tabular}{|c|c|c|c|c|c|c|c|c|c|}
\hline \multirow[b]{2}{*}{ Food groups (g) } & \multicolumn{2}{|c|}{ Photo\& 3 DR } & \multicolumn{2}{|c|}{ usual $3 D R$} & \multirow{2}{*}{\multicolumn{2}{|c|}{$\begin{array}{c}\text { Spearman } \\
r\end{array}$}} & \multicolumn{2}{|c|}{ Differences } & \multirow{2}{*}{$\begin{array}{c}\% \\
\text { differences }\end{array}$} \\
\hline & Mean & S.D. & Mean & S.D. & & & Mean & S.D. & \\
\hline Cereals & $268.2=$ & \pm 85.5 & 263.4 & \pm 84.1 & $*$ & 0.95 & $4.8=$ & \pm 18.5 & \\
\hline Potatoes and starches & $63.8=$ & \pm 38.3 & 65.3 & \pm 41.0 & & 0.95 & $-1.5=$ & \pm 12.9 & \\
\hline Sugars and sweeteners & $10.3=$ & \pm 7.6 & 10.5 & \pm 7.8 & & 0.86 & $-0.2=$ & \pm 3.1 & \\
\hline Beans & $81.1=$ & \pm 42.5 & 83.0 & \pm 44.7 & & 0.94 & $-1.9=$ & \pm 19.8 & \\
\hline Nuts and seeds & $5.9=$ & \pm 9.6 & 5.7 & \pm 9.9 & & 0.89 & $0.2=$ & \pm 2.7 & \\
\hline Vegetables & $300.3=$ & \pm 140.9 & 295.2 & \pm 142.6 & & 0.93 & $5.1=$ & \pm 42.4 & 11. \\
\hline Fruit & $174.1=$ & \pm 116.6 & 172.6 & \pm 110.6 & & 0.96 & $1.6=$ & \pm 29.0 & \\
\hline Mushrooms & $20.4 \pm$ & \pm 19.3 & 20.3 & \pm 19.4 & & 0.95 & $0.1=$ & \pm 5.0 & \\
\hline Seaweed & $12.6 \pm$ & \pm 19.8 & 12.7 & \pm 20.4 & & 0.91 & $-0.1=$ & \pm 6.7 & \\
\hline Fish and shellfish & $112.7 \pm$ & \pm 53.5 & 115.1 & \pm 58.9 & & 0.93 & $-2.3=$ & \pm 21.6 & 13. \\
\hline Meats & $76.6 \pm$ & \pm 37.1 & 76.0 & \pm 37.2 & & 0.94 & $0.6=$ & \pm 13.5 & \\
\hline Eggs & $58.6 \pm$ & \pm 28.1 & 59.6 & \pm 31.2 & & 0.96 & $-0.9=$ & \pm 11.1 & \\
\hline Milk & $158.6=$ & \pm 122.7 & 156.0 & \pm 124.4 & & 0.98 & $2.6=$ & \pm 20.6 & 20 \\
\hline Fats and oils & $8.7 \pm$ & \pm 5.3 & 8.5 & \pm 5.1 & & 0.93 & $0.2=$ & \pm 2.4 & 14 \\
\hline Confectionery & $47.7 \pm$ & \pm 46.0 & 42.5 & \pm 41.3 & * & 0.90 & $5.2=$ & \pm 23.1 & \\
\hline Beverages & $726.5 \pm$ & \pm 415.4 & 692.1 & \pm 429.6 & $*$ & 0.95 & $34.4=$ & \pm 88.2 & 12 \\
\hline Seasonings and spices & $43.7=$ & \pm 18.3 & 43.5 & \pm 18.6 & & 0.81 & $0.2=$ & \pm 1.8 & 15. \\
\hline
\end{tabular}

*; Significantly different from usual $3 D R, \mathrm{p}<0.05$. Paired t-test.

$r$; Significantly correlated in all food groups, $\mathrm{p}<0.05$

Differences; Photo\& 3 DR-usual 3 DR

\% differences; |(Photo\& 3 DR-usual 3 DR $) \mid$ usual 3 DR $\times 100$

in Table 2 . Cereals, confectioneries, and beverages showed significant differences between usual $3 D R$ and Photo\& $3 D R$, though the correlations between usual $3 D R$ and Photo\& $3 D R$ were relatively strong (from seasonings and spices; 0.81 to milk; 0.98). The percentage differences were more than $20 \%$ in potatoes and starches $(20.9 \%)$, nuts and seeds $(34.3 \%)$, mushrooms $(45.3 \%)$, seaweed $(28.9 \%)$, and in milk $(20.9 \%)$. 
Advantages of Taking Photographs with the 3-Day Dietary Record

Table 3 Comparison of nutrient intakes between usual $3 D R$ and Photo\& $3 D R$ by the subjects $(n=100)$

\begin{tabular}{|c|c|c|c|c|c|c|c|c|c|c|c|}
\hline \multirow{2}{*}{ Nutrient } & & \multicolumn{2}{|c|}{ Photo\&3DR } & \multicolumn{3}{|c|}{ usual 3DR } & \multirow{2}{*}{\multicolumn{2}{|c|}{$\begin{array}{c}\text { Spearman } \\
r\end{array}$}} & \multicolumn{2}{|c|}{ Differences } & \multirow{2}{*}{$\begin{array}{c}\% \\
\text { differences } \\
\end{array}$} \\
\hline & & Mean & S.D. & Mean & & S.D. & & & Mean & S.D. & \\
\hline Energy & ( kcal) & $2041=$ & \pm 372 & 2006 & \pm & 371 & * & 0.91 & 36 & \pm 142 & 4.9 \\
\hline Protein & $(\mathrm{g})$ & $82.7=$ & \pm 16.1 & 82.0 & \pm & 17.2 & & 0.82 & 0.8 & \pm 8.1 & 6.0 \\
\hline Fat & $(\mathrm{g})$ & $57.2=$ & \pm 15.4 & 56.2 & \pm & 15.2 & & 0.90 & 1.1 & \pm 6.1 & 7.5 \\
\hline Cholesterol & $(\mathrm{mg})$ & $374=$ & \pm 136 & 377 & \pm & 144 & & 0.95 & -4.0 & \pm 61.1 & 7.8 \\
\hline Carbohydrate & $(\mathrm{g})$ & $280.2=$ & \pm 54.6 & 274 & \pm & 56.1 & * & 0.94 & 5.8 & \pm 17.8 & 4.9 \\
\hline TDF & $(\mathrm{g})$ & $16.8=$ & \pm 5.2 & 16.5 & \pm & 5.4 & & 0.91 & 0.3 & \pm 1.9 & 7.5 \\
\hline Calcium & $(\mathrm{mg})$ & $650=$ & \pm 229 & 637 & \pm & 235 & & 0.95 & 12 & \pm 71 & 7.6 \\
\hline Iron & $(\mathrm{mg})$ & $12.1=$ & \pm 2.8 & 12.0 & \pm & 3.0 & & 0.84 & 0.1 & \pm 1.4 & 7.1 \\
\hline Salt & $(\mathrm{g})$ & $12.8=$ & \pm 3.6 & 12.6 & \pm & 3.8 & & 0.85 & 0.2 & \pm 1.6 & 9.0 \\
\hline Vitamin A & $(\mu \mathrm{g})$ & $886=$ & \pm 510 & 887 & \pm & 520 & & 0.94 & -1.6 & \pm 116 & 9.1 \\
\hline Vitamin E & $(\mathrm{mg})$ & $7.7=$ & \pm 2.0 & 7.6 & \pm & 2.0 & & 0.90 & 0.1 & \pm 0.8 & 7.6 \\
\hline Vitamin $B_{1}$ & $(\mathrm{mg})$ & $1.11=$ & \pm 0.29 & 1.09 & \pm & 0.29 & & 0.91 & 0.01 & \pm 0.11 & 6.4 \\
\hline Vitamin $\mathrm{B}_{2}$ & $(\mathrm{mg})$ & $1.53=$ & \pm 0.36 & 1.51 & \pm & 0.37 & & 0.91 & 0.02 & \pm 0.13 & 5.9 \\
\hline Niacin & $(\mathrm{mg})$ & $17.3=$ & \pm 4.6 & 17.1 & \pm & 5.0 & & 0.88 & 0.2 & \pm 2.2 & 7.8 \\
\hline Vitamin C & $(\mathrm{mg})$ & $152=$ & \pm 66 & 147 & \pm & 66 & * & 0.95 & 4.5 & \pm 16.8 & 8.7 \\
\hline
\end{tabular}

TDF; Total dietary fiber

*; Significantly different from usual $3 D R, \quad \mathrm{p}<0.05$. Paired t-test.

$r$ : Significantly correlated in all food groups, $\mathrm{p}<0.05$

Differences; Photo\& 3 DR-usual 3 DR

\% differences; | (Photo\& 3 DR-usual 3 DR $) \mid /$ usual 3 DR $\times 100$

Table 4 The numbers of foods unreported by the subjects in the usual $3 D R$, and food intakes from unreported foods

\begin{tabular}{|c|c|c|c|c|c|c|}
\hline \multirow[b]{2}{*}{ Food groups } & \multirow{2}{*}{$\begin{array}{l}\text { Numbers of } \\
\text { unreported } \\
\text { food }\end{array}$} & \multicolumn{2}{|c|}{$\begin{array}{l}\text { The ratio of unreported } \\
\text { food numbers }(\%)\end{array}$} & \multicolumn{2}{|c|}{$\begin{array}{l}\text { Food intakes } \\
\text { from unreported } \\
\text { food }(\mathrm{g})\end{array}$} & \multirow{2}{*}{$\begin{array}{l}\text { The ratio of unreported } \\
\text { food intakes to the } \\
\text { total food intakes }(\%)\end{array}$} \\
\hline & & $\begin{array}{l}\text { in total unre- } \\
\text { ported food } \\
\text { numbers }\end{array}$ & $\begin{array}{l}\text { in food } \\
\text { groups }^{\dagger}\end{array}$ & Mean & S.D. & \\
\hline Vegetables & 324 & 25.0 & 9.8 & 17.8 & \pm 26.0 & 6.6 \\
\hline Seasonings and spices & 261 & 20.2 & 8.5 & 4.0 & \pm 7.1 & 8.9 \\
\hline Beverages & 113 & 8.7 & 6.6 & 49.1 & \pm 105.8 & 8.7 \\
\hline Fish and shellfish & 79 & 6.1 & 8.0 & 6.2 & \pm 13.6 & 4.9 \\
\hline Fats and oils & 61 & 4.7 & 9.5 & 0.9 & \pm 2.1 & 9.7 \\
\hline Cereals & 60 & 4.6 & 4.3 & 4.8 & \pm 13.2 & 1.9 \\
\hline Seaweed & 54 & 4.2 & 11.8 & 1.9 & \pm 11.7 & 10.8 \\
\hline Sugars and sweeteners & 53 & 4.1 & 7.3 & 0.6 & \pm 2.0 & 6.0 \\
\hline Fruit & 52 & 4.0 & 7.2 & 8.0 & \pm 20.3 & 11.1 \\
\hline Beans & 48 & 3.7 & 5.3 & 4.0 & \pm 8.6 & 5.9 \\
\hline Milk & 37 & 2.9 & 6.4 & 4.1 & \pm 12.8 & 3.4 \\
\hline Meats & 36 & 2.8 & 5.7 & 3.2 & \pm 9.7 & 3.6 \\
\hline Eggs & 29 & 2.2 & 5.9 & 1.8 & \pm 4.2 & 3.1 \\
\hline Nuts and seeds & 26 & 2.0 & 12.6 & 0.3 & \pm 1.0 & 6.3 \\
\hline Potatoes and starches & 25 & 1.9 & 5.4 & 1.7 & \pm 5.2 & 3.5 \\
\hline Mushrooms & 20 & 1.5 & 7.3 & 1.4 & \pm 7.1 & 5.4 \\
\hline Confectionery & 17 & 1.3 & 7.2 & 1.4 & \pm 5.4 & 3.1 \\
\hline
\end{tabular}

Nutrient intake from usual $3 D R$ and Photo\& $3 D R$ are shown in Table 3 . Energy, carbohydrate, and vitamin $\mathrm{C}$ showed significant differences between usual $3 D R$ and Photo\& $3 D R$. The correlations between usual $3 D R$ and Photo\& $3 \mathrm{DR}$ were strong (from protein; 0.82 to vitamin C; 0.95). The percentage differences were $9.1 \%$ for vitamin A and $9.0 \%$ for salt, but the percentage differences were less than $10 \%$ for all nutrients.
The numbers of "unreported" foods in the usual $3 \mathrm{DR}$ by the subjects are shown in Table 4 . Among "unreported" foods, $25 \%$ of the food count was vegetables and $20 \%$ was seasonings and spices. The "unreported" count of vegetables accounted for $9.8 \%$ of total vegetables in the usual 3 DR. "Unreported" seaweed (11.8\%) and "unreported" nuts and seeds (12.6\%) also accounted for more than $10 \%$ of total seaweed and total nuts and seeds. The 
Table 5 Nutrient intakes from unreported foods in the Photo\& $3 D R$ by the subjects $(\mathrm{n}=100)$

\begin{tabular}{|c|c|c|c|}
\hline \multirow[b]{2}{*}{ Nutrient } & & $\begin{array}{l}\text { Nutrient intake } \\
\text { from unreported } \\
\text { food }\end{array}$ & $\begin{array}{l}\text { The ratio of nutrient } \\
\text { intake from } \\
\text { unreported food to } \\
\text { total nutrient intake }\end{array}$ \\
\hline & & Mean & $\begin{array}{ll}\text { Mean } & \text { S.D. }\end{array}$ \\
\hline Energy & ( kcal) & $85 \pm 123$ & $4.1 \pm 6.1$ \\
\hline Protein & $(g)$ & $3.7 \pm 6.1$ & $4.4 \pm 6.5$ \\
\hline Fat & $(\mathrm{g})$ & $3.1 \pm 4.5$ & $5.3 \pm 7.6$ \\
\hline Cholesterol & $(\mathrm{mg})$ & $14 \pm 29$ & $3.5 \pm 6.6$ \\
\hline Carbohydrate & $(g)$ & $10.6 \pm 17.1$ & $3.8 \pm 6.3$ \\
\hline $\mathrm{TDF}$ & $(\mathrm{g})$ & $1.0 \pm 1.9$ & $6.1 \pm 11.0$ \\
\hline Calcium & $(\mathrm{mg})$ & $38 \pm 72$ & $6.1 \pm 11.0$ \\
\hline Iron & $(\mathrm{mg})$ & $0.8 \pm 2.1$ & $6.4 \pm 13.4$ \\
\hline Salt & $(\mathrm{g})$ & $1.2 \pm 3.2$ & $8.1 \pm 15.2$ \\
\hline Vitamin A & $(\mu \mathrm{g})$ & $43 \pm 56$ & $6.0 \pm 8.1$ \\
\hline Vitamin E & $(\mathrm{mg})$ & $0.4 \pm 0.6$ & $5.6 \pm 7.0$ \\
\hline Vitamin $\mathrm{B}_{1}$ & $(\mathrm{mg})$ & $0.05 \pm 0.08$ & $4.5 \pm 8.1$ \\
\hline Vitamin $\mathrm{B}_{2}$ & $(\mathrm{mg})$ & $0.07 \pm 0.10$ & $4.8 \pm 6.5$ \\
\hline Niacin & $(\mathrm{mg})$ & $0.9 \pm 1.9$ & $5.1 \pm 9.2$ \\
\hline Vitamin C & $(\mathrm{mg})$ & $8 \pm 11$ & $5.5 \pm 7.7$ \\
\hline
\end{tabular}

ratios of "unreported" food intake to total food intake in the usual $3 D R$ were high for seaweed (10.8\%) and fruit (11.1\%).

Nutrient intake from "unreported" foods by the subjects are shown in Table 5 . Salt intake from "unreported" foods was $8.1 \%$ of the total. More than $5 \%$ of some nutrients in the Photo\& $3 D R$ were derived from "unreported” foods (fat; $5.3 \%$, TDF; $6.1 \%$, calcium; $6.1 \%$, iron; $6.4 \%$, vitamin A; $6.0 \%$, vitamin $\mathrm{E} ; 5.6 \%$, niacin; $5.1 \%$, and vitamin C; $5.5 \%$ ).

\section{DISCUSSION}

We conducted this study to clarify the advantages of taking photographs to estimate the kinds and amounts of food in $3 \mathrm{DR}$. It may be useful to correct the $3 \mathrm{DR}$ with photograph because about $30 \%$ of foods in the 3 DR were found to be recorded inaccurately or unreported.

As for the advantages of the photographs, this study clarified two things. First, the photographs were used to overcome variations in the reporting styles of food amounts by the subjects. When the amount of food in a meal as reported with inaccurate data as "dish or food name only" by the subjects, more than half of the records were corrected using the photographic evidence. Almost all "erroneously reported", "unreported" (excluding "seasonings and spices"), and "leftover" foods were corrected with the photographs. However, the photographs would be less important if the subjects supplied accurate data on the amounts of meals as "weight" or "portion size". In practice, "weight" was only supplied for half of the foods comsumed, and "dish or food name only" or "unreported" accounted for about $30 \%$ of the total number of foods in our study. It appears to be very difficult to obtain accurate data on the amounts of food using only self-completed records from the general public. The large-scale observational study of the Aerobics center Longitudinal Study (ACLS) has used 3 DR to assess dietary intakes in 2,307 men and 411 women. They used the portion size of food to estimate the food amounts that the subjects consumed. However, the percentage of missing portion sizes was $22 \%$ in their study ${ }^{6}$, and nearly all subjects had one or more missing portion sizes in their $3 \mathrm{DR}$. When only those participants who had no missing portion sizes in their 3 DR were included, only $6 \%$ of men and $3 \%$ of women had all three 1 -day diet records available for the study.

Second, the usefulness of the photographs depended on the meal styles recorded by the subjects. If the food as "weighed" as meal styles of "dishes", the photographs were more useful to correct the food than for "foods" or "seasonings and spices". It might be more effective to request the subjects to take photographs more carefully when they record the food in particular for; 1 ) "dishes" when they are "weighed"; 2 ) "food" when it is reported by "food name only"; 3 ) "seasonings and spices" when they are reported by "portion size" or by "food name only"; and 4) when they are leaving "leftovers" and these portions have already been recorded ("before").

For "seasonings and spices", we can expect that there are two kinds of usage. The first is as an "ingredient" of the meal, such as salt and pepper in the omelet, which are used when the food is cooked. The amounts of these kinds of seasonings might be corrected easily from the standard manual (e.g. soybean paste in miso soup or salt in grilled fish) when well-trained dietitians for our study estimate the food amounts. Welten et $\mathrm{al}^{6}$. . reported that adjusted standard portion sizes were able to replace the missing portion sizes in the ACLS database. It may be important to refine how to use both the photographs and the manuals as the situation demands ${ }^{7)}$. The other usage of "seasonings and spices" is an "addition", such as ketchup on an omelet and dressing or sauce added to salad, etc, where they were used after cooking. The usage depended on the individual preferences of the subjects. If the subjects have unique preferences for food, and these preferences are not generally accepted (i.e., mayonnaise added to rice or a generous sprinkling of soy sauce on every dish, etc) the photographs might be more useful to correct the food intakes than that of typical Japanese subjects taken from manuals. The seasonings and spices applied as an "addition" might be difficult to correct without the 
photographic evidence.

The percentage differences of food groups between $3 \mathrm{DR}$ and $3 \mathrm{DR}$ corrected with photographs were more than $20 \%$ in some food groups. Mushrooms, nuts and seeds, and milk were more easily unreported from the reports than other food groups, or these foods might have a tendency to be under-reported. Meanwhile, potatoes and starches, and seaweed might have a tendency to be overestimated. The photographs are useful for researchers to correct the accuracy of the food amounts recorded by the subjects. As for nutrient intakes, the systematic error should be less than $10 \%{ }^{\left.1{ }^{-3}\right)}$, the percentage differences for vitamin A (9.1\%) and salt (9.0\%) were in near to the border line. We should try to get these nutrient intakes more accurately from the $3 \mathrm{DR}$.

We considered the effect of unreported food because it accounted for about $20 \%$ of the final data in our study. Vegetables were often applied as garnish with main dishes and it was easy to forget reporting them. Seasonings and spices, especially additional seasoning and spices, were also frequently unreported. The ratio of unreported seaweed and nuts and seeds were slight in total unreported food numbers, but the rates of unreported foods in those food groups were higher than those of other food groups. We should ask the subjects to report seaweed and nuts and seeds intake more carefully than other foods. The rate of nutrient intake from unreported food to the total nutrient intake as less than $10 \%$ for all nutrients, but the rate of salt intake from unreported foods to the total $(8.1 \%$, in Table 5 ) was similar to the percentage difference of salt $(9.0 \%$, in Table 3$)$. The inaccuracy in salt intake values might be caused by unreported rather than inaccuracy in the amount of foods reported (i.e., reported only dish or food name).

Suzuki et $\mathrm{al}^{11)}$. reported the results of a photographic dietary assessment (the subjects took pictures of their meals and snacks instead of writing down) of 25 family members of students on a dietetic course. The inter-observer correlation between nutrient intakes by the photographic dietary assessment and by the weighed DR was very high (median of correlation coefficient; $r=0.74$ ). The method was generally acceptable to estimate nutritional intake, though some kinds of food or meals such as fish (sashimi; sliced raw fish), meats, seasonings (spread margarine on bread, salad dressing, sugar for coffee, etc), boiled food (filling of miso soup, noodle, or stew etc.), or Japanese "nabe-mono" (a one-pot dish cooked at the table, and all family members eat it together) were difficult to correct with photographs alone. It was also difficult assess salt intake information from this method. The use of an instant camera also made it easy to take the pictures meals if the subjects went eat to out, but it was difficult to grasp the leftover food or the refill food from the photographs. Other previous studies have described almost the same problems ${ }^{10,16), 17)}$.

As for eating out, the middle-aged group (40-59 years; $1.0 \pm 1.0$ times per three days) tended to eat out more frequently than older-aged group (60-79 years; $0.4 \pm 0.6$; $\mathrm{p}<0.01$ ) in our study. However, there was no significant difference in the number of photographs (middle-aged; $19.1 \pm 4.2$, older-aged; $19.4 \pm 4.0, \mathrm{p}=0.65)$. This suggests that photographs might be useful if the subjects took photographs at most meal times, and the utility of the photographs might be independent of the where the subjects ate and the age of the subjects. Wang et $\mathrm{al}^{16), 17)}$. reported that a new dietary instrument ( Wellnavi"; hand-held personal digital assistant with camera and mobile telephone card) might be a convenient instrument for evaluating dietary intake, and the method could be considered as a useful assessment instrument to assist researchers in dietary data collection. However, some food items, particularly some additional foods to major foods (seasoning, salad dressing, margarine, and cooking oil etc.), could not be visualized separately from a low resolution digital photo and might contribute to the low correlations for salt, vitamin E, saturated fatty acid, etc. It was suggested that the information on standard additions for foods might be needed to better estimate the intakes of sodium and other nutrients. The current study combined recorded information and photographic information of food. The $3 \mathrm{DR}$ with photographs applied in our study might be a useful method as well as photographic dietary assessment, "Wellnavi", or the other multimedia dietary assessment tools ${ }^{18)-21}$.

Our study has several limitations. First, some subjects could not take the photographs or could not take photographs well. The numbers of excluded subjects were not dependent on age (older-aged; $\mathrm{n}=6$, middle-aged; $\mathrm{n}=8$ ) in our study. Whether the photographs can be taken or can be taken well might be dependent on the motivation to participate in the study.

Second, subjects worried about the appearance of their meal, which may have subconsciously influenced them in food selection. Though this problem is not limited to our method alone, one of the general problems of $3 \mathrm{DR}$ with photographs has on the subjects meal preparation decisions greatly affects the validity of the study.

We would like to study of the utility of the cell phone cameras, or digital cameras, instead of the disposable camera in the near future. These devices were not widespread at the time when we conducted this study. It is also 
important to study the cost efficiency of this photograph method, and to assess the handling or maintenance of the 3 DR recording data and or photographs.

\section{CONCLUSION}

Photographs may be useful to collect or improve $3 \mathrm{DR}$ information in the following points.

1 ) Photographs may be useful to estimate values for inaccurately data in the $3 \mathrm{DR}$ such as erroneously reported, unreported, or leftover dish or foods by the subjects.

2 ) Photographs may be useful to estimate the intake of vegetables and seasonings, which were unreported relatively frequently by the subjects.

\section{Acknowledgments}

This study was partially supported by a Grant-in-Aid for Comprehensive Research on Aging and Health from the Ministry of Health, Labour and Welfare of Japan (H17choju-ippan-033). We thank the participants and colleagues in the NILS-LSA.

\section{References}

1) Willett W.: Nutritional Epidemiology second ed., Oxford university press , New York, USA, p 50-67 (1998)

2 ) Thompson FE, Byers T.: Dietary assessment resource manual, J Nutr., (suppl), 2245S-2317S (1994)

3 ) Sasaki S.: Evidence-based nutrition-EBN, Ishiyaku Publishers Inc, Tokyo, Japan, 17-32 (2001)

4 ) Cypel YS, Guenther PM, Petot GJ.: Validity of portion-size measurement aids: a review, J Am Diet Assoc, 97, 289-292 (1997)

5 ) Robson PJ, Livingstone MB.: An evaluation of food photographs as a tool for quantifying food and nutrient intakes, Public Health Nutr., 3, 183-192 (2000)

6 ) Welten DC, Carpenter RA, McPherson RS, et al.: Comparison of a dietary record using reported portion size versus standard portion size for assessing nutrient intake, Public Health Nutr., 3,151-158 (2000)

7 ) Imaeda N, Tokudome Y, Fujiwara N, et al.: Data checking and standardization in a weighed food dietary record survey, Jpn J Nut, 58, 67-76 (2000)
8 ) Ishida H, Imaeda N, Takahashi T, et al.: Manual for dietary assessment, Nanzandou, Tokyo, Japan, 107-149 (2005)

9) Nelson M, Atkinson M, Darbyshire S.: Food photography II: use of food photographs for estimating portion size and the nutrient content of meals, Br. J. Nut, 76, 31-49 (1996)

10) Kawamura T, Yatsuhashi M, Shimizu Y, et al.: Validity of photographical dietary assessment; a preliminary analysis, Nippon Koshu Eisei Zasshi, 42, 992-998 (1995)

11) Suzuki A, Miyauchi M, Hattori I, et al.: Inter-observer agreement and validity of photographic dietary assessment, Nippon Koshu Eisei Zasshi, 49, 749-758 (2002)

12) Imai $T$, Sakai $S$, Mori $K$, et al.: Nutritional assessments of 3 -day dietary records in National Institute for Longevity Sciences-Longitudinal Study of Aging, J Epidemiol., 10 (suppl), S70-S76 (2000)

13) Shimokata H, Ando F, Niino N.: A new comprehensive study on aging-the National Institute for Longevity Sciiences, Longitudinal Study of Aging (NILS-LSA), J Epidemiol., 10 (suppl), S 1-S 9 (2000)

14) Resources Investigation Committee,: The Science and Technology Agency. Tables of Japanese Food Compositions 5 th ed., Printing Office, Ministry of Finance, Tokyo, Japan (2000)

15) SAS Institute Inc.: SAS/STAT user' s guide. Version 9.1. Cary NC, SAS Institute Inc (2006)

16) Wang DH, Kogashiwa M, Ohta S, et al.: Validity and reliability of a dietary assessment method: the application of a digital camera with a mobile phone card attachment. J Nutr Sci Vitaminol., 48, 498-504 (2002)

17) Wang DH, Kogashiwa M, Kira S.: Development of a new instrument for evaluating individuals' dietary intakes, J. Am. Diet. Assoc., 106, 1588-1593 (2006)

18) Williamson DA, Allen HR, Martin PD, et al.: Comparison of digital photography to weighed and visual estimation of portion sizes. J Am Diet Assoc., 103, 1139-1145 (2003)

19) Yon BA, Johnson RK, Harvey-Berino J, et al.: The use of a personal digital assistant for dietary self-monitoring does not improve the validity of self-reports of energy intake. J Am Diet Assoc., 106, 1256-1259 (2006)

20) Zoellner J, Anderson J, Gould SM.: Comparative validation of a bilingual interactive multimedia dietary assessment tool, J Am Diet Assoc., 105, 1206-1214 (2005)

21) Kaczkowski $\mathrm{CH}$, Jones PJ, Feng J, et al.: Four-day multimedia diet records underestimate energy needs in middle-aged and elderly women as determined by doubly-labeled water, $J$ Nutr., 130, 802-805 (2000) 